\title{
PERBANDINGAN RUMAH TINGGAL TRADISIONAL JAWA DAN RUMAH TINGGAL MODERN DI SURAKARTA
}

\author{
Fillia Mutiara Sari, Dhani Mutiari \\ Program Studi Teknik Arsitektur, Fakultas Teknik, Universitas Muhammadiyah Surakarta \\ Jl. A. Yani Tromol Pos 1 Pabelan Kartasura Sukoharjo 57102 Telp 0271-717417 \\ Emal : dhani.mutiar@yahoo.com
}

\begin{abstract}
ABSTRAK
Rumah tinggal di Jawa Tengah bermula dari bentuk arsitektur tradisional Jawa lebih banyak dikenal dengan bangunan Joglo. Joglo merupakan kerangka bangunan utama dari rumah tradisional Jawa yang terdiri dari soko guru yaitu berupa empat tiang utama penyangga struktur bangunan serta tumpang sari yang berupa susunan balok yang disangga soko guru. Sebenarnya atap rumah Jawa tidak hanya joglo tetapi juga atap limasan dan kampung. Pemakaian atap ini sebenarnya adalah cara sebuah rumah untuk beradaptasi dengan iklim tropis yang berada di Jawa Tengah. Searah dengan perkembangan waktu muncullah perumahan perumahan baru dengan berbagai tipe di Surakarta. Rumah dengan gaya modern telah menjadi gaya hidup ketimbang sekadar berfungsi utama sebagai desain bangunan rumah tinggal. Disain rumah tinggal modern yang lahir di Eropa tidak dapat begitu saja diaplikasikan di Surakarta karena iklim yang berbeda. Penelitian ini bertujuan untuk membandingkan rumah tinggal tradisonal jawa dengan rumah tinggal modern yang terdapat di Jawa Tengah. Metode yang digunakan adalah melakukan survey terhadap rumah tradisional Jawa dan rumah modern, kemudian membandingkan rumah tinggal tradisional dan mencari sesuatu yang diaplikasikan untuk rumah tinggal modern. Dalam penelitian ini ditemukan bahwa ada 3 hal yang diaplikasikan yaitu orientasi bangunan, rumah tunggal dan bukan kopel dan adanya langit langit.
\end{abstract}

\section{Kata Kunci: perbandingan, rumah tradisional, rumah modern}

\section{PENDAHULUAN}

Bangunan Joglo sebagai salah satu bangunan tradisional Jawa di dalamnya terkandung filosofi yang sesuai dengan kehidupan masyarakatnya. Susunan ruangan pada Joglo umumnya dibagi menjadi tiga bagian yaitu ruangan pertemuan yang disebut pendopo, ruang tengah atau ruang yang dipakai untuk mengadakan pertunjukan wayang kulit disebut pringgitan, dan ruang belakang yang disebut dalem atau omah jero sebagai ruang keluarga. Dalam ruang ini terdapat tiga buah senthong (kamar) yaitu senthong kiri, senthong tengah dan senthong kanan. Pendopo sebagai ruang terbuka berfungsi untuk menerima tamu. Struktur bangunan pada pendopo menggunakan umpak sebagai alas soko, 4 buah soko guru (tiang utama) sebagai simbol 4 arah mata angin dan 12 soko pengarak, serta tumpang sari merupakan susunan balok yang disangga oleh soko guru. Umumnya tumpang sari terdapat pada pendopo bangunan yang disusun bertingkat. Tingkatan-tingkatan ini dapat pula diartikan sebagai tingkatan untuk menuju pada suatu titik puncak, yang terdiri dari seriat, tarekat, hakekat, dan makrifat. Menurut kepercayaan jawa, tingkatantingkatan ini akan menyatu pada satu titik. Ndalem ini adalah pusat susunan ruang-ruang di sekitarnya. Fungsi utamanya adalah sebagai ruang keluarga. Sifat ruangan ini pribadi, suasana yang ada di dalamnya tenang dan berwibawa. Pada pola tata ruang ndalem terdapat perbedaan ketinggian lantai sehingga membagi ruang menjadi 2 area. Pada lantai yang lebih rendah di gunakan sebagai sirkulasi sedangkan pada bagian yang lebih tinggi digunakan sebagai ruang keluarga dan senthong.

Kebutuhan rumah tinggal dewasa ini berkembang sangat pesat. Munculnya perumahan dengan berbagai variasi, dari 
rumah susun hingga real estate, menunjukkan kebutuhan manusia akan rumah selalu meningkat. Dengan mengacu pada konsep urban, model bangunan real estate banyak mengadopsi arsitektur luar seperti arsitektur mediterania, arsitektur spanyol (adanya pilar).

\section{IDENTIFIKASI MASALAH}

a. Bagaimana karakter rumah tinggal tradisonal Jawa dan rumah tinggal modern di Surakarta?

b. Apa saja pengaruh budaya dan tradisi rumah tradisional Jawa terhadap rumah tinggal modern di Surakarta?

c. Bagaimana konsep rumah tinggal tradisional yang dapat diaplikasikan dalam rumah tinggal modern dan faktor-faktor apa yang mempengaruhinya?

\section{BATASAN MASALAH}

a. Menetapkan Kota Karesidenan Surakarta sebagai wilayah kajian.

b. Kajian akan difokuskan pada rumah tinggal tradisional Jawa dan rumah tinggal modern

\section{TINJAUAN PUSTAKA}

Rumah dalam arti fisik, merupakan tempat sebagian besar kegiatan domestik dilakukan, termasuk cara mengkomunikasikan gagasan atau ekspresi diri penghuni yang terikat budaya. Rumah mengalami perubahan akibat meningkatnya pengetahuan manusia dari yang sederhana ke tingkat yang lebih kompleks. Pengetahuan ini membantu mengarahkan manusia memahami nilai, konsepsi, atau paham yang membimbing tindakan dalam upayanya mencari pengalaman yang harmonis untuk mencapai ketenangan, ketentraman, dan keseimbangan batin. Pandangan mengenai konsep kemapanan dalam bertempat tinggal memberikan gambaran keberadaan dan status seseorang, yang memungkinkannya memiliki kontrol territorial terhadap ruang spasialnya. Rumah hanya salah satu cara yang nyata untuk mewujudkan upaya menghuni suatu tempat, yang terdiri dari struktur bangunan fisik yang memuat satuan simbolis, sosial dan praktis (Revianto, 2003).

$$
\text { Rumah merupakan salah satu }
$$
kebutuhan utama manusia, sehingga perencanaan pembangunan rumah harus cermat dan mempertimbangkan banyak hal. Beberapa diantaranya, yaitu potensi fisik dan potensi sosial budaya. Potensi fisik adalah pertimbangan akan bahan bangunan, kondisi geologis dan iklim setempat. Sedangkan, potensi sosial budaya terdiri atas arsitektur lokal dan cara hidup (Dinas Kimpraswil, 2002). mempertimbangkan faktor iklim. Salah satu jenis rumah modern yang muncul adalah rumah sederhana. Rumah sederhana merupakan jenis rumah yang dibutuhkan oleh sebagian besar masyarakat Indonesia yang mayoritas menengah kebawah. Rumah ini memiliki keterbatasan berupa luas bangunan, luas tanah, konstruksi dan bahan bangunan. Karena keterbatasan tersebut, rumah sederhana kurang dapat menangani permasalahan iklim dengan baik, sehingga kondisi di dalam bangunan dinilai kurang nyaman dan cenderung lebih panas. Selain itu, faktor lingkungan sekitar yang cenderung terbatas dan padat turut pula membentuk kondisi ketidaknyamanan tersebut, mengingat kondisi dalam dan luar bangunan saling mempengaruhi (Soegijanto, 1999). Oleh karena itu, perhatian terhadap perancangan rumah sederhana beserta lingkungannya, atau dapat pula disebut perumahan sederhana, sangat diperlukan.

\section{METODE PENELITIAN Metode Penelitian}

Metode yang digunakan adalah metode kualitatif. Analisis menggunakan metode deskreptif komparatif, menggambarkan kondisi faktual dengan mengemukakan fakta-fakta yang ada di lapangan serta membandingkannya antara satu kondisi dengan kondisi lainnya.

\section{Tinjauan Lokasi}

Kasus diambil di 2 lokasi, lokasi pertama adalah di Patihan, Sragen Jawa Tengah, yang merupakan kawasan permukiman yang masih kental dengan rumah tinggal tradisionalnya. Lokasi yang kedua adalah di perumahan mojosongo yang merupakan kawasan perumahan yang relatf baru dengan karakter modern. 


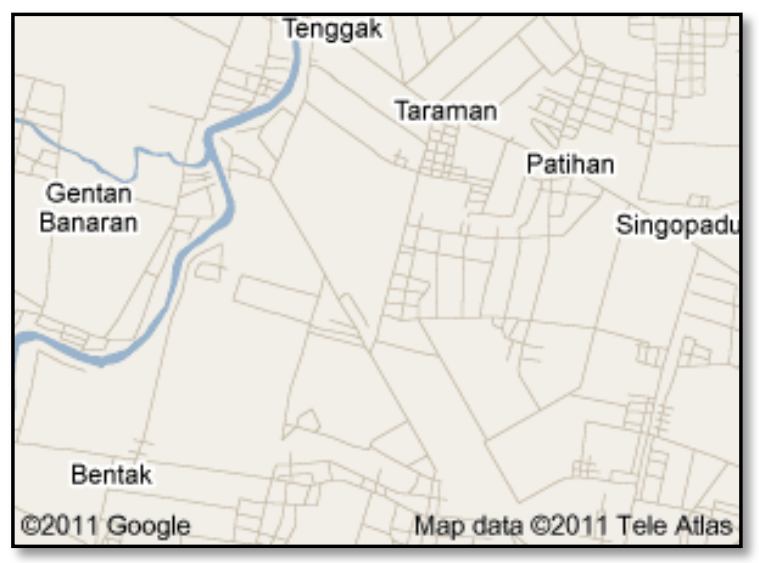

Gambar 1. Peta lokasi Patihan, Sragen, Jawa Tengah Sumber: www.googlemap.com,2012

\section{Bahan Penelitian}

Pembahasan mengenai sarana dan prasarana hanya yang terkait dengan kedua variabel, seperti jalan atau ruang terbuka hijau saja. Dari variabel tersebut diperoleh atribut yang lebih spesifik untuk diteliti secara mendalam , yaitu sebagai berikut:

a. Lingkungan rumah tinggal

1) Orientasi bangunan

2) Bangunan sekitar dan vegetasi

b. Rumah sederhana

1) Posisi bangunan dan tata ruang

2) Bentuk bangunan

3) Selubung bangunan, yang terdiri atas:

- Dinding

- Atap

- Bukaan atau ventilasi

Peneltian dilakukan dengan kuesioner, observasi dan wawancara .

\section{Teknik Pengolahan Data}

Sesuai dengan tahapan kegiatan, proses pengolahan dilakukan dengan cara membandingkan antara rumah tinggal tradisional dengan rumah tinggal modern.

a. Tahap 1 : Mencari masing masing karakter pada rumah tinggal tradisional dan rumah tinggal modern.

Langkah awal adalah pemaparan kondisi eksisting sesuai dengan variabel kajian berdasarkan data yang telah dikumpulkan.

b. Tahap2 : Membandingkan antara konsep rumah tinggal tradisional dan rumah tinggal modern. Tahap ini bertujuan untuk melihat konsep-konsep apa yang terdapat dalam rumah tinggal tradisional dan rumah tinggal modern.

\section{HASIL dan PEMBAHASAN \\ Gambaran Kasus}

Hasil pengamatan rumah tradisional Jawa di daerah Patehan Sragen terdapat dua karakter yang pertama adalah rumah dengan fungsi rumah tinggal (Gb.2 dan 3) dan rumah dengan fungsi rumah lumbung padi (gb.4). Keduanya menggunakan atap Joglo Lambangsari (Gb.5 dan 6)

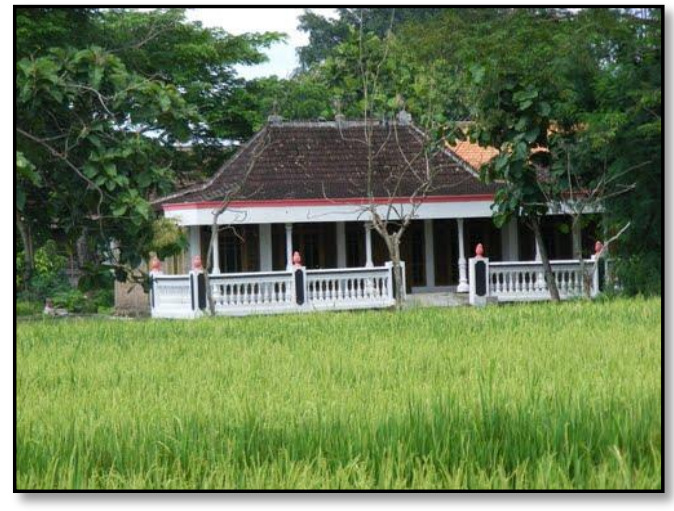

Gambar 2. Rumah Jawa di Patihan,sragen Jawa Tengah

Sumber: Hasil pengamatan,2012

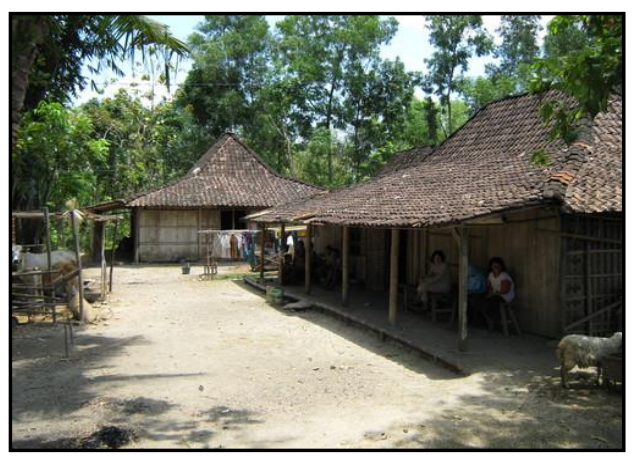

Gambar 3. Rumah Jawa di Patihan,sragen Jawa Tengah

Sumber: Hasil pengamatan,2012

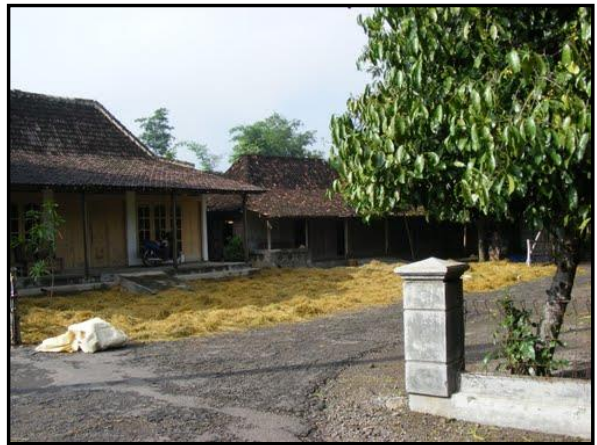

Gambar 4. Rumah lumbung padi di Patihan,sragen Jawa Tengah

Sumber: Hasil pengamatan,2012 


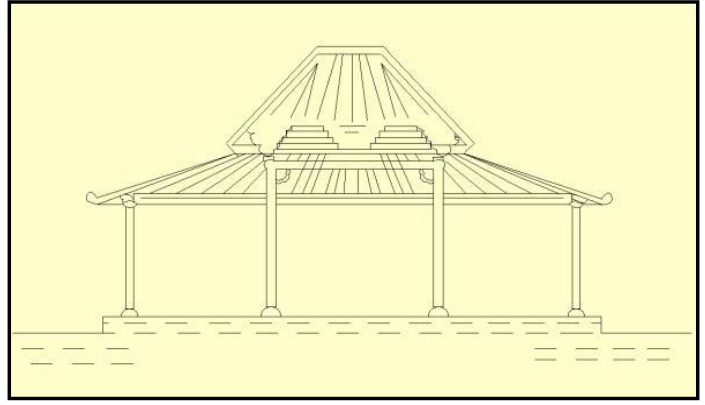

Gambar 5. Joglo Lambangsari

Sumber: presty larasati , arsitektur tradisional

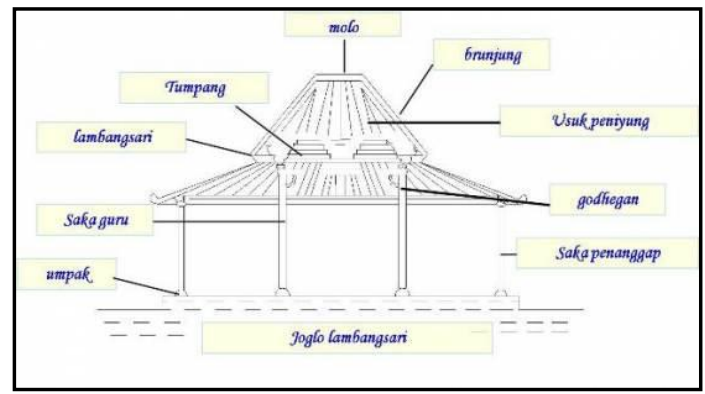

Gambar 6. Potongan Joglo lambangsari Sumber: presty larasati , arsitektur tradisional

Pengamatan Rumah Tinggal modern dilakukan di kawasan perumahan Mojosongo Pratama Jebres Mojosongo Surakarta. Pada kawasan perumahan ini diambil satu tipe rumah sebagai contoh untuk diamati adaptasi dari tradisionalnya $(g b, 6,7,8)$.

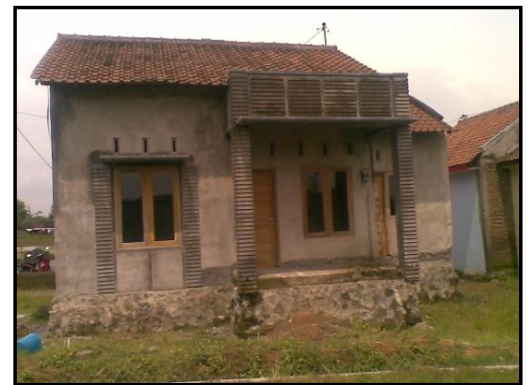

Gambar 7. Rumah modern Perumahan Mojosongo Pratama, Jebres Surakarta Sumber: Hasil pengamatan

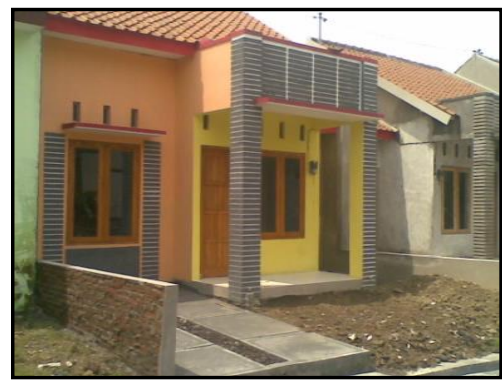

Gambar 8. Tampak depan rumah modern Sumber: Hasil pengamatan

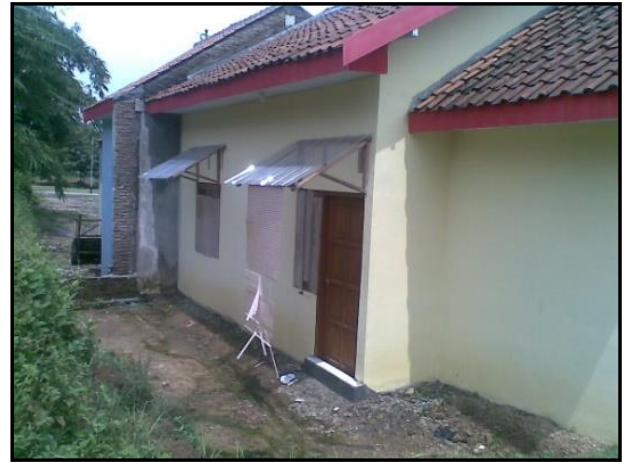

Gambar 9. Tampak belakang rumah modern Sumber : Hasil pengamatan

\section{ANALISA DATA \\ Karakteristik Rumah tinggal Tradisional Jawa dan Lingkungannya}

Rumah dalam kehidupan budaya Jawa adalah rumah atau halaman atau persil yang terletak pada suatu titik di suatu wilayah tertentu, dalam bentuk ruang dengan ukuran yang terbatas, sambil meninjau kembali keadaannya di masa lalu dan memikirkan keadaan dirinya pada waktu sekarang maka tempat itu dapat dipergunakan untuk beristirahat, tanpa harus mengganggu kegiatan-kegiatannya saat ini yang sangat bermanfaat untuk mempersiapkan dirinya dalam rangka menghadapi kehidupan di masa yang akan datang agar supaya kehidupan ini dapat tetap berjalan mengikuti perkembangan jaman dan dalam waktu yang bersamaan dapatlah juga dipergunakan untuk mendewasakan dirinya (Ronald, 2005). Secara umum, sebagian besar rumah orang Jawa memiliki denah dasar yang sama namun perbedaan jenis atap yang digunakan menunjukkan kedudukan sosial dan ekonomi pemilik rumah. Secara garis besar, tempat tinggal orang Jawa dapat dibedakan menjadi rumah bentuk Joglo, Limasan, Kampung, Masjid dan Tajug atau Tarub serta Panggang Pe. Namun, terdapat tiga jenis atap yang utama, yaitu kampung, limasan dan joglo. Atap kampung adalah jenis yang paling sederhana berdasar struktur dan dikenal sebagai tempat tinggal orang biasa; atap limasan merupakan ragam bentuk atap kampung yang lebih rumit dan digunakan untuk rumah keluarga Jawa yang berkedudukan lebih tinggi; atap joglo secara tradisonal dikaitkan dengan tempat kediaman keluarga bangsawan (Ismunandar, 2003). 
Hal lain yang terkait dengan rumah Jawa adalah proporsi luasan bangunan adalah 2:3, 3:4, 3:3 atau 3:5; tinggi bangunan 2,5 kali tinggi manusia rata-rata; sistem perlubangan menggunakan penghalang berupa seketeng atau rana, jeruji, tirai kayu, dinding penghalang dan pohon penghalang; terdapat permainan irama, terlihat pada tinggi rendah pohon dan langit-langit ruangan; batas privasi terasa transparan, pagar pembatas pendek, memungkinkan untuk saling berinteraksi namun tetap terbatasi; dan fungsi ruang publik maupun privat memiliki perbedaan perlakuan, misalnya ruang publik menggunakan dinding terbuka atau berupa tiang-tiang saja.

\section{Bentuk tata ruang rumah tradisional dan modern}

\section{a. Rumah tradisional di Surakarta}

Bangunan Pendopo segi empat atau segi panjang, beratap joglo dan semua sisinya disambung emper. Pada emper depannya sering dibuatkan kuncung, yaitu atap yang menonjol dengan tujuan agar kendaraan dapat berhenti merapat di depan pendopo, sehingga penumpang yang turun dari kendaraan dapat masuk pendopo. Pendopo ini merupakan bangunan yang terbuka yang sering dipergunakan untuk menerima tamu resmi, untuk pertemuan, dan untuk pesta. Lantai pendopo itu 40 sampai $50 \mathrm{~cm}$ lebih tinggi dari pada lantai emper.

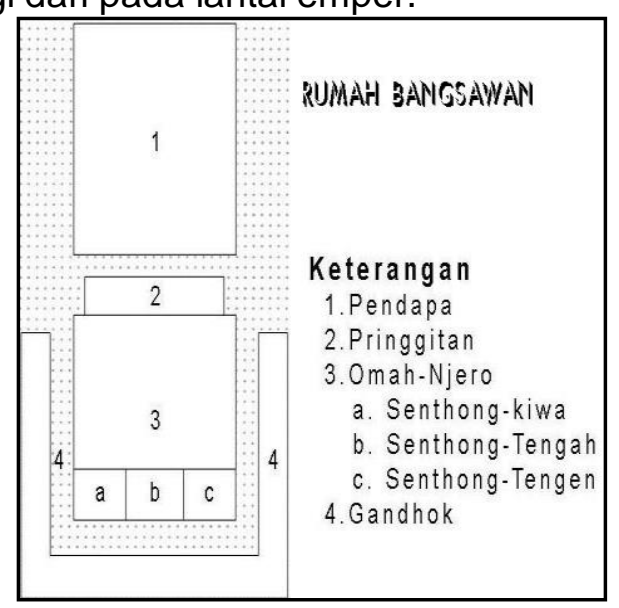

Gambar 10. Rumah tradisional Jawa Bangsawan Sumber : Dakung, Arsitektur Tradisional, Dokumentasi Kebudayaan Daerah, 1982

Susunan ruang dalam bangunan tradisional Jawa pada prinsipnya terdiri dari beberapa bagian ruang yaitu :
1. Pendopo, difungsikan sebagai tempat melakukan aktivitas yang sifatnya formal (pertemuan,upacara, pagelaran seni dan sebagainya). Meskipun terletak di bagian depan, pendopo bukan merupakan ruang penerima yang mengantar orang sebelum memasuki rumah. Jalur akses masuk ke rumah yang sering terjadi adalah tidak dari depan melalui pendapa, melainkan justru memutar melalui bagian samping rumah

2. Pringgitan, lorong penghubung (connection hall) antara pendopo dengan omah njero. Bagian pringgitan ini sering difungsikan sebagai tempat pertunjukan wayang kulit / kesenian / kegiatan publik. Emperan adalah teras depan dari bagian omah-njero. Teras depan yang biasanya lebarnya sekitar 2 meter ini merupakan tempat melakukan kegiatan umum yang sifatnya nonformal.

3. Omah njero, kadang disebut juga sebagai omah-mburi, dalem ageng atau omah. Kata omah dalam masyarakat Jawa juga digunakan sebagai istilah yang mencakup arti kedomestikan, yaitu sebagai sebuah unit tempat tinggal.

4. Senthong-kiwa, dapat digunakan sebagai kamar tidur keluarga atau sebagai tempat penyimpanan beras dan alat bertani.

5. Senthong-tengah (krobongan), sering juga disebut sebagai boma, pedaringan, atau krobongan. Dalam gugus bangunan rumah tradisional Jawa, letak senthong-tengah ini paling dalam, paling jauh dari bagian luar. Senthong-tengah ini merupakan ruang yang menjadi pusat dari seluruh bagian rumah. ruang ini seringkali menjadi "ruang pamer" bagi keluarga penghuni rumah tersebut. Sebenarnya senthong-tengah merupakan ruang yang sakral yang sering menjadi tempat pelaksanaan upacara / ritual keluarga. Tempat ini juga menjadi ruang penyimpanan benda-benda pusaka keluarga penghuni rumah.

6. Senthong-tengen, fungsinya sama dengan sentong kiwa. 
7. Gandhok, bangunan tambahan yang mengitari sisi samping dan belakang bangunan ini.

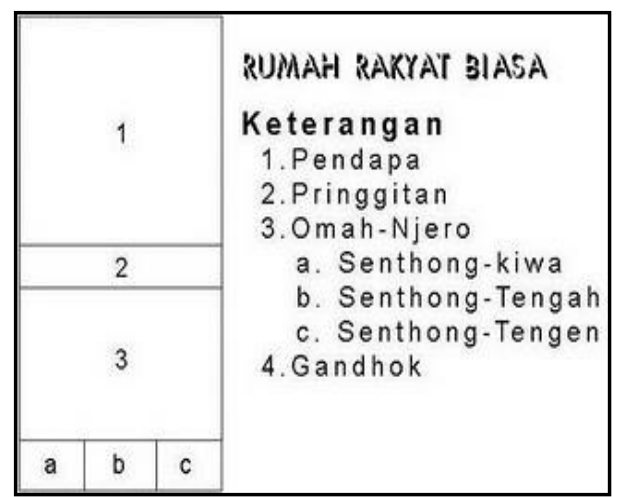

Gambar 11. Rumah tradisional Jawa Rakyat Biasa Sumber : Dakung, Arsitektur Tradisional, Dokumentasi Kebudayaan Daerah, 1982

Bagi orang Jawa, baik sebagai individual maupun anggota masyarakat, realita itu tidak dibagi-bagi secara terpisahpisah dan tanpa hubungan satu sama lain, melainkan ia dilihat sebagai satu kesatuan yang menyeluruh. Bagi orang Jawa dunia masyarakat dan dunia gaib, atau dunia Adi Kodrati bukanlah tiga bidang yang berdiri sendiri-sendiri, dan masing - masing mempunyai hukumnya sendiri, melainkan merupakan satu kesatuan pengalaman. Pada hakekatnya, orang Jawa tidak membedakan antara sikap religius atau tidak religius dan interaksi-interaksi sosial religius, tetapi ketiganya merupakan penjabaran manusia Jawa tentang sikapnya terhadap alam, seperti halnya sikap alam yang sekaligus mempunyai relevansi sosial. Di sini antara pekerjaan, interaksi, dan doa tidak ada perbedaan yang hakiki (Mulder, 1975:36).

\section{b. Rumah tinggal modern di Surakarta}

Rumah tinggal modern di Mojosongo Surakarta memiliki karakter disain sebagai berikut :

1. Orientasi bangunan searah dengan sumbu Utara-Selatan, sehingga lebih berpotensi menurunkan suhu.

2. Posisi bangunan bermassa tunggal guna mendapatkan ventilasi silang. Dimensi bukaan yang lebih berpotensi menurunkan suhu adalah bukaan ventilasi berdimensi kecil. Pada uji simulasi, dimensi yang dibuat berukuran $2 \mathrm{~m} \times 0,05 \mathrm{~m}$.
3. Rasio perbandingan bentuk rumah yang paling ideal untuk menurunkan suhu adalah 2:3.

4. Posisi bukaan berfungsi untuk memasukkan cahaya.

5. Batas ketinggian ruang dengan atau tanpa langit-langit adalah 2,8m. Jika tidak menggunakan plafon, maka ketinggian ruang harus ditinggikan agar memperoleh suhu yang lebih rendah.

6. Vegetasi pada lingkungan rumah tradisional Jawa didominasi oleh pohon buah-ekstrim.

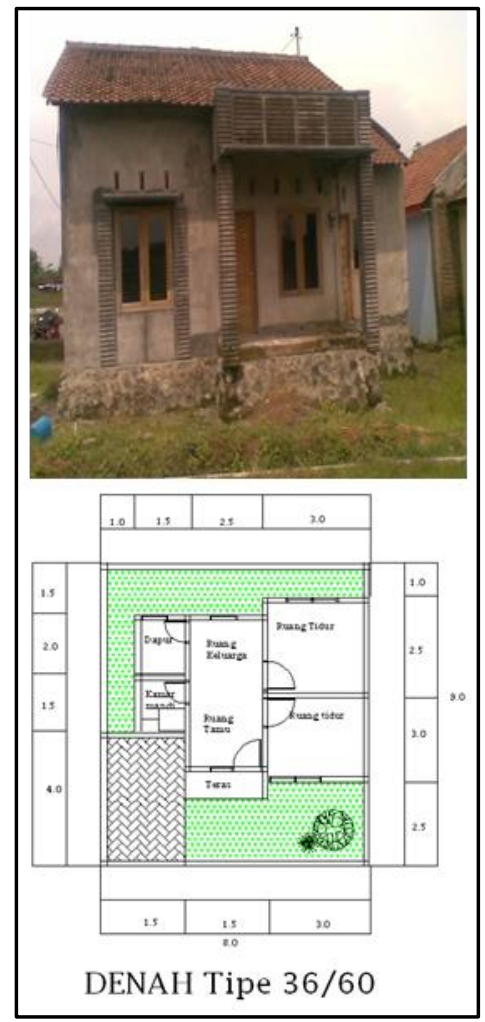

Gambar 12. Denah dan rumah tampak depan perumahan Mojosongo, Jawa Tengah Sumber : Hasil Survey

\section{Perbandingan antara rumah tinggal tradisional dan rumah tinggal modern}

Sebagian besar kriteria desain yang terdapat pada rumah tinggal modern di Mojosongo merupakan modifikasi dari prinsip rumah tradisional Jawa seperti orientasi bangunan yang mengarah ke Utara-Selatan, masa bangunan tunggal dan arah bukaan yang memaksimalkan cahaya matahari. Prinsip tersebut dapat diterapkan pada perumahan sederhana, karena termasuk dalam cara pengendalian secara alami atau 
berdasarkan pada iklim, namun, terdapat satu variabel yang tidak murni berdasarkan prinsip rumah tradisional Jawa, yaitu pada pengadaan langit-langit. Secara desain rumah tradisional Jawa, sebenarnya elemen ini tidak termasuk bagian di dalam rumah tersebut, akan tetapi dalam perkembangan teknologi saat ini, elemen langit-langit ini ternyata menjadi penting. Berdasarkan hasil modifikasi rumah sederhana, jika tidak menggunakan langit-langit, maka ruang perlu ditinggikan. Penambahan ketinggian tentunya dapat menyebabkan penambahan biaya. Sehingga, pengadaan langit-langit sangat diperlukan pada perumahan sederhana ini. Rekomendasi yang disarankan adalah ketinggian ruang 2,4 meter dengan menggunakan langit-langit.

\section{KESIMPULAN}

Ungkapan tata hidup masyarakat Jawa dalam tata ruang rumah, diwujudkan dengan melekatnya atribut fungsional ( guna) dengan atribut nilai (makna) rumah. Rumah tinggal Jawa mengungkapkan konsep yang terkandung dan aturan demi kesepakatan masyarakat, melalui latar belakang sosial budaya religius dan kepercayaan. Terdapat orientasi yang jelas dalam ungkapan tata ruang, yaitu sumbu Utara-Selatan dan pusat dualitas. Orientasi menyatakan posisi,perilaku dan peristiwa. Akibat perkembangan budaya dan perilaku masyarakat sekarang, maka tidak bisa mengembangkan sepenuhnya konsep formulasi ruang yang menjadi kesepakatan sosial masyarakat Jawa. Namun kesepakatan tersebut menjadi pelajaran berharga dalam penataan rumah dan lingkungannya. Hal hal yang terdapat pada rumah tinggal tradisional yang diterapkan pada rumah tinggal modern di mojosongo adalah :

a. Orientasi bangunan yang mengarah pada Utara-Selatan untuk menghasilkan udara yang nyaman , b. Rumah dengan masa tunggal untuk menghasilkan udara yang cross ventilation.

Hal hal yang tidak sama adalah dalam hal penggunaan langit-langit. Pada rumah tradisional tidak mengenal adanya langit langit atau cenderung menempel pada atap, sedang rumah modern sederhana menggunakan langit langit.

\section{SARAN}

Terbatasnya kajian yang dilakukan dengan tema penerapan prinsip pengetahuan arsitektur tradisional dan modern, berpengaruh terhadap hasil kajian ini. Oleh karena itu, dirumuskan beberapa saran yang sebaiknya dilakukan untuk menyempurnakan kajian dengan tema tersebut, khususnya kajian ini. Antara lain sebagai berikut:

a. Perencanaan baru rumah tingal modern sederhana cenderung menggunakan langit langit. Sebenarnya hal ini akan mengurangi kenyamanan, jika tetap menggunakan langit-langit, maka ruang perlu ditinggikan. Untuk menghasilkan sirkulasi udara yang lebih baik di sarankan rumah tinggal modern di Mojosongo untuk dapat menaikkan langit langitnya.

b. Perlu dilakukan pengujian lebih lanjut pada posisi dan bentuk bukaan dengan simulasi, yaitu posisi di bawah, tengah atau atas; dan posisi melintang atau membujur.

c. Belum tersedianya program simulasi yang dapat menguji keterkaitan lingkungan luar terhadap kondisi menyebabkan keterbatasan dalam melakukan kajian dan eksplorasi dalam perancangan. Oleh karena itu, perlu dicari solusi penyelesaian masalah tersebut untuk kemajuan ilmu pengetahuan, dan teknologi bangunan.

d. Proses kajian serupa dapat pula dilakukan dengan dasar prinsip arsitektur tradisional yang lain, tidak hanya rumah tradisional Jawa.

\section{DAFTAR PUSTAKA}

Arya Ronald. 2004. Nilai-nilai Arsitektural Rumah Tradisional Jawa. Gadjah Mada University Press. Yogyakarta.

Dakung S. 1982. Arsitektur Tradisional Yogyakarta. Dokumentasi Kebudayaan Daerah. 
Harusatoto. Budiono. 1987. Simbolisme Dalam Budaya Jawa. Yogyakarta. PT Hamindita.

Ismunandar K.R. 1993. Joglo. Dahara Prize. Semarang.

Ismunandar. 2003. Rumah Tradisional Jawa. Dahara Prize. Semarang.

Koentjoroningrat. 1984. Kebudayaan Jawa. Jakarta. Balai Pustaka.

Revianto. 2000. Omah: Membaca Makna Rumah Jawa. Yayasan Benteng Budaya. Yogyakarta. 200:3

Dinas Kimpraswil. 2002 